\title{
PERCEPTION OF PRESCHOOLERS (3-7 YEARS) ON USAGE OF YOUTUBE IN SEMARANG
}

\author{
Nanang Sahriana, Yuli Kurniawati Sugiyo Pranoto \\ Universitas Negeri Semarang, Semarang, Indonesia \\ e-mail: nanang.sahriana@gmail.com
}

\begin{abstract}
This study aims to obtain preliminary data related to children's perceptions of gadgets and YouTube and what content is often watched by children. YouTube is one website on the internet that can be accessed easily to exchange information in the form of videos. Respondents in this study were preschool children, amounting to 30 children (17 girls and 13 men) with a range of 3-7 years in Semarang City. This study uses a qualitative approach. Collecting data in this study uses methods of observation, interviews, drawing and documentation of the work in the form of images of children. The results showed that $96.7 \%$ of children felt like using YouTube because they could watch various favorite videos and how to access them was very easy. There are $93.3 \%$ of children using smartphones parental to open YouTube and of course with parental supervision. Judging from the picture of the child, there is a tendency with the age of a higher child having the ability to visualize what is watched on YouTube more clearly, when compared to younger children. Content that is often watched by children varies greatly, including Paw Patrol Cartoon (23.3\%), Play-doh (20\%), Tayo (13.2\%), Robocar Poli (10\%), Bibo Toys (6.7\%), Lego (6.7\%), Upin Ipin (6.7\%), Tendangan dari Langit $(6.7 \%)$ and other cartoons (6.7\%). With the ease of accessing information on social media such as YouTube, parent policy plays an important role, in addition to the positive side there is also a negative side that can affect children's growth and development. The government is also expected to take a firm stance regarding freedom of access to information that is not child friendly, such as content containing pornography.
\end{abstract}

Keywords: child perception, gadget, YouTube usage, child images, preschool

\section{INTRODUCTION}

\subsection{Definition and Functions of Gadgets}

Technology development is currently experiencing rapid growth. This can be proven by the many innovations that have been carried out in this world. One example is in the form of a gadget. It seems that gadgets can have a huge impact on cultural values. Now everyone in the world must have a gadget. Nowadays gadget users don't only come from among the workers. But almost all people including children and toddlers have used gadgets in activities they do every day. Almost everyone who uses gadgets spends a lot of their time in a day using gadgets. Therefore the gadget also has its own values and benefits for certain people.

A gadget is a small electronic device that has special functions day by day. Gadgets always appear by presenting the latest technology that makes human life more practical (Efendi, 2014). According to the Big Indonesian Dictionary, gadgets are electronic or mechanical devices that have practical functions (kbbi.kemdikbud.go.id). Gadgets are identical to small objects that can be carried anywhere. Objects such as smartphones, tablets, $\mathrm{mp} 3$ are some of the popular gadgets today. Who is not familiar with smart phone technology, aka smartphone? Almost everyone uses this technology in everyday life. 
The gadget has functions and benefits that are relatively in accordance with its users. Functions and benefits of gadgets in general include:

\section{Communication}

Knowing human beings is increasingly widespread and advanced. If in ancient times humans communicated through the heart, then developed through writing sent by post. Now the era of globalization, people can communicate easily, quickly, practically and more efficiently by using mobile phones.

\section{Social}

Gadgets have many features and applications that are right for us to be able to share news, news and stories. So that the utilization can add friends and establish distant kinship relationships without having to use a relatively long time to share.

\section{Education}

As time goes by, learning is not only focused on books. But through the gadget we can access the various sciences we need. About education, politics, general knowledge, religion, without having to bother going to a library that might be far to reach.

\subsection{YouTube Application}

One of the applications that is often accessed by children on smartphones is YouTube. YouTube is a website that facilitates its users to share videos they have, or limited to enjoying various video clips uploaded by various parties. There are various kinds of videos that can be uploaded to this site, such as music video clips from certain musicians, short films, television films, movie trailers, educational videos, vlogger video blogs, various video tutorials, and many more. Unregistered users can watch videos, while registered users can upload an unlimited number of videos.

The use of YouTube as a learning tool by young people is currently influenced by their characteristics as digital native. YouTube as a result of technological development certainly does not escape the view of this generation. They have a tendency to turn to the internet when looking for answers to something interesting than asking other people or reading books. Time and cost limitations are also an option consideration when studying on YouTube.

\subsection{Giving Gadgets to Children}

Many parents give free to their children by buying gadgets from an early age. Because access is very fast and free, just by typing in the keywords, the video you are looking for will appear immediately, this backfires for the parents themselves if there is no supervision of their children. Most research on children and digital media has focused on children aged 9 years and over. However, due to the recent advances of touch screen devices most children use digital media and the internet at an earlier age (Findahl, 2013).

According to the e-Marketer survey company, gadget users have increased significantly in Indonesia and are predicted to enter the top four populations of the world's biggest gadget users in 2016 (Source: id.korantempo.com, 2015). A study has just been released by the American Association of Pediatrics (AAP). This study takes the title "the use of media is dominant in the lives of children today". The most common media used by children are gadgets, the number of children who use gadgets almost doubled (from 38 percent to 72 percent), and more and more babies are 1 year old (Warisyah, 2015).

\subsection{Negative Impact of Gadgets}

But there are problems that arise regarding the provision of gadgets to children, namely the habits of children who use smartphones have an influence on the ability of the brain to capture information (Adriyanto \& Dra. Taufik Suprihartini, 2016). At present, the use of gadgets or smartphones is unavoidable, and one thing that is often overlooked is the negative effects of gadget radiation can affect the health of the human body, especially for children. The reason why most people, especially children, ignore this fact is because of lack of supervision from their parents or guardians (Vincent Jonathan S., Dr. Prayanto WH, M.Sn., Hen Dian Yudani, ST, 2011).

Child growth and development experience a very fast process at an early age. A child's growth and development is influenced by heredity and environment factors. In the era of globalization, information technology is part of the environment of child development. Parents and parties with an interest in the child's growth and development cannot close themselves to the phenomenon. The development of technology and communication if 
addressed wisely and child-friendly will help facilitate the stimulation of child development (Mulyani, 2015).

A child psychologist Anna Surti Ariani said, if a child plays gadgets too often, it will reduce children's insight and intelligence because a child needs concrete insight in the world. In line, Dr. Setyo Handryastuti, Sp.A (K) said, disagreement if parents have started giving a gadget to children, especially toddlers. According to him, the gadget is not one of the right media used for children's play facilities (http://digital.metrotvnews.com/anakdigital/).

In addition to the adverse effects on children's health, many negative impacts that will arise include difficult socialization, slow motoric development, and significant behavioral changes. So it is very important the role of parents to monitor, control and pay attention to all children's activities (Chusna, 2017). One study that explains that if parents allow children to continuously use gadget applications that will make early childhood difficult to concentrate in learning, lazy to write, lazy to read books and experience a decline in the quality of the child in socializing. Not to mention, the gadget has a lot of negative effects if it is used continuously, one of which is like a mental disorder. There are still many other problems that arise from the use of gadgets that are carried out continuously (Maulida, 2013).

In addition, some teachers report that gadgets are not safe for preschoolers if too much time is spent on them (Yee, Seok, Hashmi, Teng, \& Indran, 2016). The majority of excessive gadget users have a bad attitude. The overwhelming majority of users $(90 \%)$ state that they feel sad, anxious, or angry when their gadget is taken (Master et al., 2016).

Here are some of the negative effects of gadgets for child development (Hastuti, 2012):

\section{Difficulty Concentrating on the Real World.}

A sense of addiction or addiction to gadgets will make children easily bored, restless and angry when he was separated by his favorite gadget. When a child feels comfortable playing with his favorite gadget he will be more fun and happy to be alone playing the gadget. As a result the child will experience difficulty interacting with the real world of friends and playing with peers.

\section{Disruption of PFC Functions}

Addiction to technology can further affect children's brain development. PFC or Pre Frontal
Cortex is a part of the brain that controls emotions. self control, responsibility, decision making and other moral values. Children who are addicted to technology such as online games of the brain will produce dopamine hormone excessively which results in impaired PFC function.

\section{Introvert}

Dependence on gadgets for children makes them assume that the gadget is everything for them. They will be upset and anxious if they are separated from the gadget. Most of their time is spent playing with gadgets. As a result, not only the lack of closeness between parents and children also tends to be introverted.

\subsection{Drawing}

Drawing becomes one of the most popular and effective techniques in research involving children. Some studies that use techniques drawing or also known as techniques artwork such as those done by MacNaughton et al, for children aged 8 years and over who live in displacement (Pranoto, 2018: 59).

This drawing technique is considered effective because it provides an opportunity for children to think about what will be written in the picture, and the image may be added, or even replaced. It is important that drawing allows children to express their perspectives, imagination and interpretation of the world (Sapkota \& Sharma in Thomas and O'Kane in Pranoto, 2018: 60).

There are various reasons for using images in research with early childhood, including images can be used as good ice breakers, can help children to relax and build good relationships with researchers, can act as clues and as triggers to remember or raise discussion, and can help children to build their own narratives.

This technique also allows children to gain more control over the interview process because it gives children the opportunity to draw as much or as little as they want and also gives them time to reflect on their own ideas. It has been described as a useful and fast enough way to get a considerable amount of information in a relatively short time. 


\section{Method}

\subsection{Participants}

Participants in this study were preschool aged 30 children (17 girls and 13 men) with a range of ages 3-7 years in Semarang.

\subsection{Procedure}

This study uses a qualitative approach. Data collection in this study uses observation methods, structured interviews, drawing and documentation of the work in the form of images of children. Interviews take place in schools and children's homes. The duration of structured interviews with children is between 35 and 85 minutes (an average of 60 minutes).

Children already have access to this device. One child has his own device. In this study, we describe the results of interviews with children and also from pictures of children.

This study aims to obtain preliminary data related to children's perceptions of YouTube and what content is often watched by children. How to monitor parents for children who are given freedom by owning their own smartphone.

Table 1. Detailed Description of Participants

\begin{tabular}{ccccc}
\hline $\begin{array}{c}\text { Child } \\
\text { Code }\end{array}$ & Age & Device & Duration & School grade \\
\hline A1 & 6 & No & $40 \mathrm{~min}$ & TK Negeri Pembina \\
A2 & 5 & No & 1 hour & TK Al-Huda \\
A3 & 3 & No & $30 \mathrm{~min}$ & PAUD Ceria Nanda \\
A4 & 3 & No & 1 hour & PAUD Ceria Nanda \\
A5 & 5 & No & $30 \mathrm{~min}$ & PAUD Ceria Nanda \\
A6 & 5 & No & $30 \mathrm{~min}$ & PAUD Ceria Nanda \\
A7 & 4.5 & No & $30 \mathrm{~min}$ & PAUD Ceria Nanda \\
A8 & 4 & No & $30 \mathrm{~min}$ & PAUD Ceria Nanda \\
A9 & 4.3 & No & $30 \mathrm{~min}$ & PAUD Ceria Nanda \\
A10 & 3.6 & No & $30 \mathrm{~min}$ & PAUD Ceria Nanda \\
A11 & 6 & No & $30 \mathrm{~min}$ & TK Negeri Pembina \\
A12 & 5 & No & $30 \mathrm{~min}$ & Labschool Unnes \\
A13 & 4 & No & $30 \mathrm{~min}$ & TK Al-Madina \\
A14 & 6 & No & $30 \mathrm{~min}$ & TK Al-Madina \\
A15 & 7 & No & $30 \mathrm{~min}$ & TK Al-Madina \\
A16 & 7 & No & $30 \mathrm{~min}$ & SDN 1 Petompon \\
A17 & 7 & No & $30 \mathrm{~min}$ & SDN 1 Petompon \\
A18 & 7 & No & $30 \mathrm{~min}$ & SDN 1 Petompon \\
A19 & 7 & No & $45 \mathrm{~min}$ & SDN 1 Petompon \\
A20 & 6 & Yes & 5 hours & TK Sampangan
\end{tabular}

\begin{tabular}{lcccc} 
A21 & 7 & No & $30 \mathrm{~min}$ & SDN 2 Petompon \\
A22 & 7 & No & $30 \mathrm{~min}$ & SDN 2 Petompon \\
A23 & 7 & No & $30 \mathrm{~min}$ & SDN 2 Petompon \\
A24 & 7 & No & $30 \mathrm{~min}$ & SDN 2 Petompon \\
A25 & 7 & No & $30 \mathrm{~min}$ & SDN 2 Petompon \\
A26 & 4.6 & No & $30 \mathrm{~min}$ & PAUD Ceria Nanda \\
A27 & 3 & No & 4 hours & PAUD Ceria Nanda \\
A28 & 4.5 & No & $30 \mathrm{~min}$ & PAUD Ceria Nanda \\
A29 & 4 & No & 2.5 hours & PAUD Ceria Nanda \\
A30 & 3 & No & $30 \mathrm{~min}$ & PAUD Ceria Nanda \\
\hline
\end{tabular}

\section{RESULT AND DISCUSSION}

\subsection{Duration of Child Using the Gadget}

Amount of time a child uses or duration using a gadget to watch on YouTube in one day varies between 30 minutes to 5 hours, and no child does not watch on YouTube.

The duration of the child watching on YouTube every day gives a picture of still being safe for children. Recommendations from the Children's Media Education Foundation (YPMA) and institutions others who care about the health of the child's development are children watching television or on YouTube up to 2 hours a day (Pradekso, 2015). If using the guidelines, around $90 \%$ of respondents who watch YouTube healthy based on its duration. The remaining $10 \%$ are classified as unhealthy, some watch YouTube for up to 5 hours every day.

This amount of time is truly extraordinary for children aged 3 to 7 years because this amount is not equivalent to the amount of time the child uses to study at school every day. A very large number considering various positive activities that should be carried out by children.

Data regarding the duration and frequency of children watching on YouTube everyday shows that the intensity of watching children is quite low, although there are 3 children whose duration is quite high. Regardless of whether television can influence children's behavior (especially negative behavior) or not, the tendency of gadget consumption in children is a real symptom.

\subsection{Ownership of Gadgets}

One important factor that influences the use of gadgets in children is the problem of ownership of the gadget itself and internet access (quota) available. Of the 30 children studied, there was only 
one child who had own ownership, so that the child freely used it. The ease of accessing information offered makes children tend to have difficulty choosing things that are indeed offered for children or for adults. From these conveniences arise children's curiosity to access more adult content that triggers criminal or immoral acts that are based on high curiosity that makes them practice it. So it can be said that providing gadgets to children without supervision from parents will tend to have a negative impact.

According to Chusna (2017) many parents give their children the freedom that is as free as possible by buying gadgets from an early age. They reasoned that the action would be safer and easier in monitoring the activities of the baby.

When compared to other children who do not have their own gadgets, they have to borrow from their parents or siblings if they want to access YouTube, and of course the duration or duration of watching is limited. Parents who lend gadgets to children, usually have set up internet access to turn off so that children are not free to open the YouTube application, so that children are more likely to play offline educational games that have been provided by parents. In this study, the phenomenon related to the ownership of gadgets and internet access is very influential on children's access to YouTube.

\subsection{Child Perception about YouTube}

Children are specific audiences. Broadcasting regulators specifically provide protection to groups of children who are not exposed to television programs that are not suitable for their age. But unlike on YouTube, almost all information can be accessed easily and quickly.

The content on YouTube is very likely to be watched as well as specific and typical to be associated with children, such as cartoons. Nonetheless, submit further events on commercial observations and looseness of control in children, providing a very broad opportunity for children to be exposed to the content of the program that is not intended for the audience of children. But like stated by Huston and colleagues that children aged 8 or 9 have been able to distinguish between facts and fiction from the television programs they watch.

The poor quality of television programs is available for Indonesian children and antisocial programs and delinquency among children cannot be denied is a difficult fact. The influence of media on children is determined by their understanding of watching TV (Pradekso, 2015). The results of research indicated that parents have moderate to low levels of awareness, involvement and monitoring in their children 's Facebook usage (Asnat Dor1 \& Dana Weimann-Saks, 2013).

\subsection{Content Preferences on YouTube}

The results showed that out of 30 children 96.7\% felt happy using YouTube because they could watch a variety of their favorite videos and how to access them was very easy by entering keywords that would be displayed immediately. According to the child, to be able to access YouTube only by recognizing the symbol without having to read it first because the child is familiar with the symbol. There are $93.3 \%$ of children use smartphones parents' to open YouTube and of course with parental supervision, $3.4 \%$ belong to their own children because parents reason that these actions will be safer and easier in monitoring their child's activities.

Content that is often watched by children varies greatly, including Paw Patrol Cartoon, Playdoh, Tayo, Robocar Poli, Bibo Toys, Lego, Upin Ipin, Tendangan dari Langit, and other cartoons, as described in the table below.

Table 2. Videos that are often watched by preschoolers on youtube

\begin{tabular}{lcc}
\hline \hline \multicolumn{1}{c}{ Video Content } & Amount & Results \\
\hline Paw Patrol Cartoon & 7 & $23.3 \%$ \\
Play-doh & 6 & $20 \%$ \\
Tayo & 4 & $13.2 \%$ \\
Robocar Poli & 3 & $10 \%$ \\
Bibo Toys & 2 & $6.7 \%$ \\
Lego & 2 & $6.7 \%$ \\
Upin Ipin & 2 & $6.7 \%$ \\
Tendangan dari Langit & 2 & $6.7 \%$ \\
lainnya & 2 & $6.7 \%$ \\
\hline Total & 30 children \\
\hline \hline
\end{tabular}

With easy access to information on social media such as YouTube, the policy of the parents is very important, in addition to the positive side there is also a negative side which can affect child development. 


\section{Picture of Children}

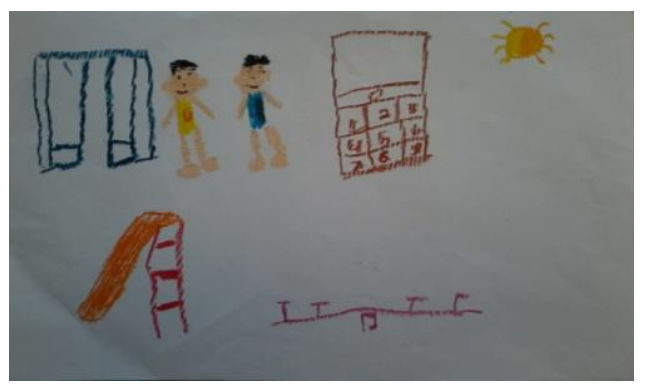

Figure 1. Hana (7 years)

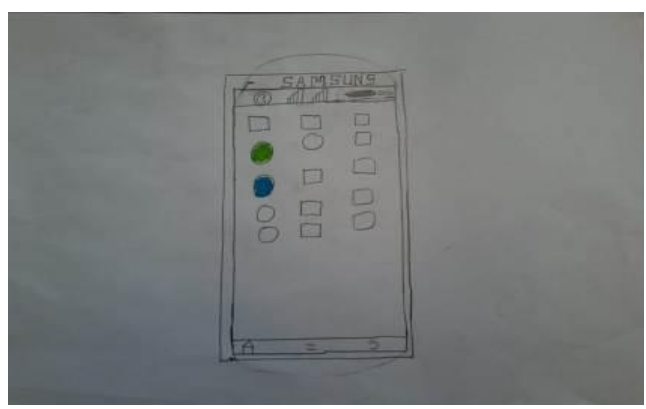

Figure 2. Naura (7 years)

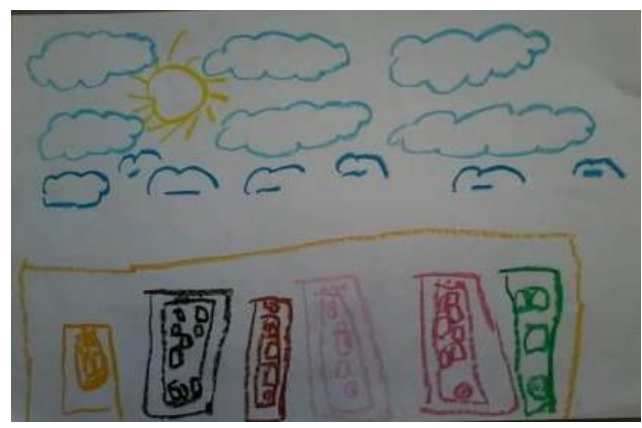

Figure 3. Adinda (6 years)

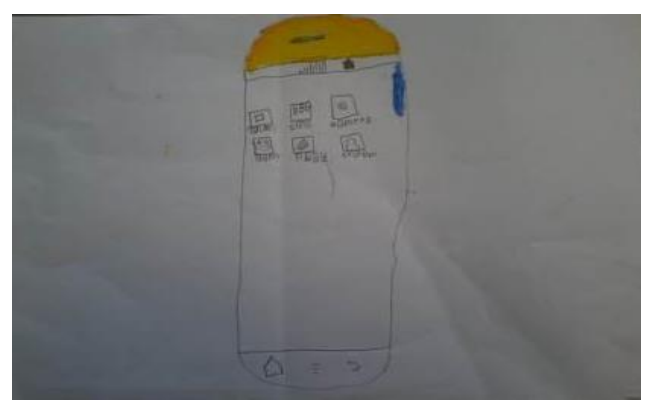

Figure 4. Kirana (6 years)

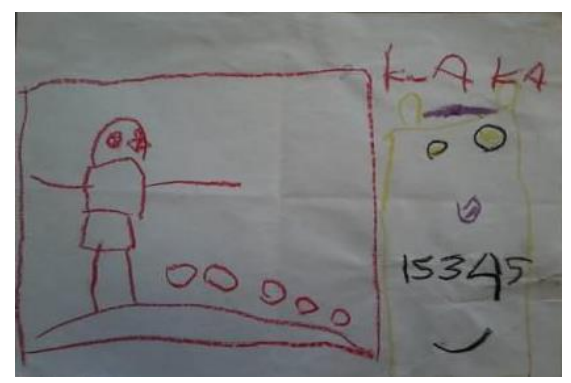

Figure 5. Khanza (5 years)

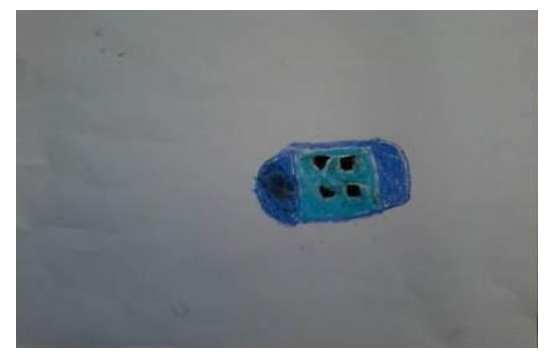

Figure 6. Alvaro (6 years)

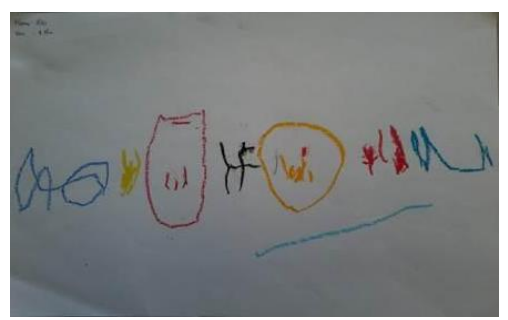

Figure 7. Alvis (4 years)

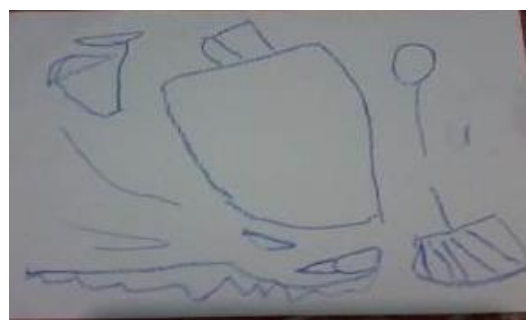

Figure 8. Hani (3 years)

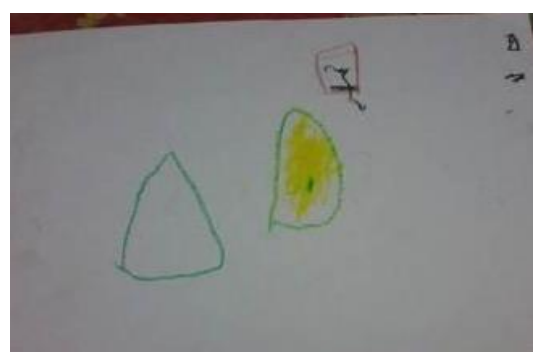

Figure 9. Vallen (3 years) 
Judging from the picture of a child, there is a tendency for older children to have the ability to visualize what is watched on YouTube more clearly, when compared to younger children. At around 7 years old children are able to visualize smartphone images well, when asked about the smartphone components children are able to answer correctly, there are even children who are able to mention the brands and applications in detail that are on smartphones, this is because children are used to using objects that. Children have been able to tell and describe what they have watched on YouTube.

\section{Conclusion}

Thus, it can be said that YouTube is one of the most frequently accessed websites by preschoolers, where it certainly has both negative and positive impacts. The role of parents is very much needed in this case as protection against watching that is not appropriate for children on YouTube. One of the important factors that influence the use of gadgets in children is the problem of ownership of the gadget itself and internet access (quota) available. The results showed that out of 30 children there were 96.7\% who were happy to use YouTube because they could watch various of their favorite videos and how to access them very easily.

Based on the child's picture, there is a significant difference between perceptions about gadgets or smartphone where children with a higher age can visualize images very well and even be able to clearly mention the components on a smartphone compared to younger children.

Suggestions that can be conveyed are as follows: 1) parents are expected to be more creative in educating early childhood so that they are not affected by the existence of gadgets, smartphones or Android tablets, 2) Every parent should supervise and limit children's access to YouTube, 3) The government is also expected to take a firm stance regarding freedom of access to information that is not child-friendly, such as videos containing adult content.

\section{REFERENCES}

[1] Adriyanto, R., \& Dra. Taufik Suprihartini, M. S. (2016). Intensity of Use Gadget Against Learning Achievement Among Children In
Elementary School Students. Interaksi Online, 4(4), 1-11.

[2] Asnat Dor \& Dana Weimann-Saks. (2013). Children's Facebook Usage: Parental Awareness, Attitudes and Behavior. Studies in Media and Communication. Vol. 1, No. 1; June 2013

[3] Chusna, P. A. (2017). Pengaruh Media Gadget Pada Perkembangan Karakter Anak. Dinamika Penelitian, 17(2), 315-330.

[4] Efendi, M. F. (2014). Pengaruh Gadget Terhadap Anak. Efendi, Muhammad Fuad.

[5] Findahl, O. (2013). Swedes and the Internet 2013. Stockholm: The Internet Infrastructure Foundation.

[6] Hastuti. 2012. Psikolog Perkembangan Anak. Yogyakarta: Tugu Publisher.

[7] Master, M. K., Kaur, C. P., Narasimhan, A., Nadeem, M., Äli, M., \& Shaik, R. B. (2016). Impact of electronic gadgets on psychological behavior of middle school children in UAE. In Gulf Medical Journal (Vol. 5, pp. 54-60).

[8] Maulida, O. H. (2013). Menelisik Pengaruh Penggunaan Aplikasi Gadget terhadap Perkembangan Psikologis Anak Usia Dini. Universitas Negeri Semarang.

[9] Mulyani, D. (2015). Tumbuh Kembang Anak Usia Dini di Era Teknologi dan Komunikasi. In Child Well-Being and Chld Protection (p. 301).

[10] Pradekso, Tandiyo. (2015). Persepsi anak pada acara televisi. Jurnal ilmu sosial. Vol. 14, No. 2 November 2015, Hal. 11-23.

[11] Pranoto, Yuli Kurniawati S. 2018. Metodologi Penelitian Kualitatif. Semarang: Widya Karya.

[12] Smahelova, M., Juhová, D., Cermak, I., \& Smahel, D. (2017). Mediation of young children's digital technology use: The parents' perspective. Cyberpsychology: Journal of Psychosocial Research on Cyberspace, 11(3), article 4. http://dx.doi.org/10.5817/CP2017-3-4

[13] Vincent Jonathan S., DR. Prayanto W.H., M.Sn., Hen Dian Yudani, S.T., M. D. (2011) Gadget Terhadap Anak. Perancangan Board Game Mengenai Bahaya Radiasi Gadget Terhadap Anak, 1-15.

[14] Warisyah, Y. (2015). Pentingnya "Pendampingan Dialogis" Orang Tua Dalam Penggunaan Gadget Pada Anak Usia Dini. Prosiding Seminar Nasional Pendidikan "Inovasi Pembelajaran Untuk Pendidikan Berkemajuan, 130-138.

[15] Yee, H. K., Seok, C. B., Hashmi, S. I., Teng, T. L., \& Indran, R. (2016). Why gadget usage among preschoolers should matter to teachers? A pilot study. GESJ: Education Science and Psychology 2016, 3(40), 98-111.

[16] https://kbbi.kemdikbud.go.id/entri/gadget. online 12 Juli 2018

[17] http://digital.metrotvnews.com/anakdigital/ online 12 Juli 2018

[18] https://id.theasianparent.com/memberikangadget-pada-anak/ online 12 Juli 2018 